\title{
Transparency at Home: How Well Do Governments Share Human Rights Information with Citizens?
}

\section{Citation}

Creamer, Cosette, and Beth Simmons. 2013. Transparency at Home: How Well Do Governments Share Human Rights Information with Citizens? In Transparency in International Law, ed. Andrea Bianchi and Anne Peters, 239-267. Cambridge: Cambridge University Press.

\section{Published Version}

http://www.cambridge.org/us/academic/subjects/law/public-international-law/transparencyinternational-law

\section{Permanent link}

http://nrs.harvard.edu/urn-3:HUL.InstRepos:12421629

\section{Terms of Use}

This article was downloaded from Harvard University's DASH repository, and is made available under the terms and conditions applicable to Other Posted Material, as set forth at http:// nrs.harvard.edu/urn-3:HUL.InstRepos:dash.current.terms-of-use\#LAA

\section{Share Your Story}

The Harvard community has made this article openly available.

Please share how this access benefits you. Submit a story.

\section{Accessibility}




\title{
Transparency at Home: How Well Do Governments Share Human Rights Information with Citizens?
}

\author{
COSETTE CREAMER AND BETH A. SIMMONS*
}

\section{Introduction}

Over the past few decades, an increasing number of States have adopted access-to-information laws or other institutions designed to make available information about government decisions and activities. ${ }^{1}$ A number of factors have made possible this trend toward greater governmental transparency. The spread of democratic government worldwide, the emergence of a global civil society, the proliferation of international regimes requiring States to disclose information, and the widespread availability of information and communication technologies have all likely contributed to the global transparency trend. ${ }^{2}$ Underlying these pressures is a strong belief that transparency influences, among other things, the quality and efficiency of governance.

The purpose of this chapter is to contribute to our knowledge about the role of transparency in safeguarding and improving human rights, as

* Alexander Noonan and Ashley DiSilvestro provided invaluable research assistance. We also benefited from discussions of an earlier version of this chapter at the authors' retreat for 'Transparency in International Law' and at the International Law-International Relations Workshop at Harvard University. All errors remain ours alone.

1 John M. Ackerman/Irma E. Sandoval-Ballesteros, 'The Global Explosion of Freedom of Information Laws', Administrative Law Review 58 (2006), 85-130.

2 There is no commonly agreed upon definition of transparency. Some scholars and international organizations employ a definition that focuses on ensuring public access to information. For Ann Florini, transparency refers to the 'degree to which information is available to outsiders that enables them to have informed voice in decisions and/or to assess the decisions made by insiders'. Ann Florini, 'Introduction: The Battle Over Transparency', in Ann Florini (ed.), The Right to Know: Transparency for an Open World (New York: Columbia University Press, 2007), 1-16, 5. Others employ definitions that reference, in addition, the scope, accuracy and timeliness of information provided. 
one element of governance. We define transparency as the dissemination of regular and useful information. ${ }^{3}$ Many studies assume that information about government policies and practices helps improve compliance with international and domestic human rights law, ${ }^{4}$ but they have not documented how and to what extent information-enhancing institutions and practices have been ensconced at the international and especially the domestic levels. We argue that one critical window into this matter is the establishment of national human rights institutions (NHRIs). NHRIs are independent governmental bodies specifically mandated to protect and promote human rights, and represent focal institutions for the provision of transparency about rights law and practice at the national level. We argue that the efficaciousness of these institutions depends on how and whether they actually inform people about the nature of human rights law and how individuals can act on this knowledge if they think their rights have been violated. Nowadays, websites represent the main tool by which NHRIs inform citizens of these matters. We show that NHRI websites are now commonplace, but recognize they are only potentially useful if they work, are navigable, and provide information that citizens can use to hold their governments and private actors accountable.

Not all NHRI websites rate highly in this regard and display considerable differences in the quality and quantity of information provided. We find that internet penetration within a country is a very strong predictor of a useful and user-friendly NHRI human rights website. Unsurprisingly, however, it is impossible to attribute better rights practices to this 'window' per se. Internet penetration itself is strongly associated with better rights practices across countries. We think it likely that NHRIs contribute in a small way to transparency in the human rights domain, but that their effects cannot be disentangled from the transparency effects of the internet more generally.

This chapter proceeds as follows. In the second section, we discuss theories of compliance with international human rights obligations, and the potential role of transparency in encouraging improved human rights practices. The third section discusses the role of NHRIs in monitoring, promoting, and educating people about their rights. We show

3 Ronald B. Mitchell, 'Sources of Transparency: Information Systems in International Regimes', International Studies Quarterly 42 (1998), 109-130, 109.

4 Xinyuan Dai, International Institutions and National Policies (New York: Cambridge University Press, 2007); Beth A. Simmons, Mobilizing for Human Rights: International Law in Domestic Politics (New York: Cambridge University Press, 2009). 
they have spread over time, that most now have websites, and that many of these websites are operable and in fact do contain information about local and international law in a form comprehensible to laypersons. The fourth section employs statistical analyses to assess the conditions associated with the existence of highly transparent websites, and the fifth section explores correlations between these sites and human rights practices. We are far from providing a causal model linking transparency with better human rights, but note that both internet penetration and more transparent NHRI websites are associated with better rights practices in countries around the world. While we think it highly likely that governments that respect human rights are more willing to be more transparent about their human rights obligations, practices and available remedies, we also conclude that a better window on government practices may reinforce positive developments by enhancing the ability of individuals and groups to stay informed and hold governments and other actors accountable for their actions.

\section{Transparency and Human Rights: The State of the Art}

In the context of human rights, transparency refers to the provision and accessibility of information about: (a) the specific human rights guaranteed, both internationally and nationally, to citizens, and what these rights mean in practice; (b) the procedures and legal processes available to ensure realization of their rights; and (c) a government's policies and practices of human rights protection. ${ }^{5}$ Under this definition, human rights transparency is viewed not as an end in itself but as an instrument for improving States' human rights practices. The consumers of this information are both citizens affected by a government's human rights practices, and international treaty bodies and NGOs tasked with monitoring these practices.

Transparency is often cited as the solution to a host of development and governance problems. The claimed benefits of greater transparency are many: it can improve investment climates and financial market performance more generally; it can promote public debate and improve policy-making; and it can increase the ability of legislatures, the media and civil society to hold policy-makers accountable, thereby increasing

${ }^{5}$ These are similar to the elements of transparency identified by Abraham Chayes/Antonia Handler Chayes, The New Sovereignty: Compliance with International Regulatory Agreements (Cambridge Mass.: Harvard University Press, 1995), 135-153. 
public trust and confidence in government. There are thus a number of theoretical reasons to expect greater transparency to improve States' compliance with human rights obligations, as transparency is often viewed as contributing to increased accountability of governments to both international and domestic actors. More specifically, most theories of compliance with international law rely explicitly or implicitly on the availability of information about government activities and legal obligations.

Still, international human rights treaties do not establish a legal obligation on States to be transparent about their human rights practices. None of the nine major human rights treaties, or their optional protocols, mention transparency in relation to States. ${ }^{6}$ The only use of the word 'transparent' is found within article 35(4) of the Convention on the Rights of Persons with Disabilities, which provides that ' $[w]$ hen preparing reports to the Committee, States Parties are invited to consider doing so in an open and transparent process'. ${ }^{7}$ In particular, States 'shall closely consult with and actively involve persons with disabilities, including children with disabilities, through their representative organizations' ${ }^{8}$ In contrast, the Convention against Torture explicitly provides for the absence of transparency, in the form of confidential inquiries under article 20 into the systematic practice of torture within a country. ${ }^{9}$ In terms of dissemination of information about human rights, the Convention on the Rights of the Child is the only treaty to provide that State parties are to 'undertake to make the principles and provisions of the Convention widely known, by appropriate and active means, to adults and children alike'. ${ }^{10}$

${ }^{6}$ Convention against Torture and Other Cruel, Inhuman or Degrading Treatment or Punishment, 10 December 1984, 1465 UNTS 85; Convention on the Elimination of All Forms of Discrimination against Women, 18 December 1979, 1249 UNTS 13; Convention on the Rights of the Child, 20 November 1989, 1577 UNTS 3; International Convention on the Elimination of All Forms of Racial Discrimination, 21 December 1965, 660 UNTS 195; Convention on the Rights of Persons with Disabilities, 13 December 2006, 2515 UNTS 3; UNGA, Resolution Adopted by the General Assembly: International Convention for the Protection of All Persons from Enforced Disappearance, A/RES/61/177, 12 January 2007, annex; International Convention on the Protection of the Rights of All Migrant Workers and Members of their Families, 18 December 1990, 2220 UNTS 93; International Covenant on Civil and Political Rights, 16 December 1966, 999 UNTS 171; International Covenant on Economic, Social and Cultural Rights, 16 December 1966, 993 UNTS 3.

7 Convention on the Rights of Persons with Disabilities, 2006 (n 6), art. 35(4).

8 Ibid., art. 4(3). 9 Convention against Torture, 1984 (n 6), art. 20.

10 Convention on the Rights of the Child, 1989 (n 6), art. 42. 
Much of the early human rights scholarship implicitly viewed transparency at the international level as a key mechanism to encourage compliance with human rights obligations. By ratifying international human rights treaties, States became legally obligated to be open about their human rights practices as well as their efforts to implement treaty obligations. Every major human rights convention establishes an independent oversight committee to which States are required to submit periodic reports on the legislative, judicial, administrative or other measures adopted to give effect to human rights obligations. Most human rights conventions, though, do not require States to otherwise disseminate these periodic reports. The Convention on the Rights of the Child and the International Convention on the Protection of the Rights of All Migrant Workers and Members of Their Families are exceptions, as they provide that 'States Parties shall make their reports widely available to the public in their own countries'. ${ }^{11}$ After considering periodic State reports, each committee then typically provides concluding observations and often requests additional information. Each committee is also permitted to transmit its concluding observations and the State reports themselves to other relevant international agencies. ${ }^{12}$

Through these periodic reports, governments are required to provide information to the treaty committees on their human rights practices and efforts to comply. If States fall short in this regard, the committee - through its concluding observations - often publicly identifies non-compliant States, thereby engaging in a practice of 'naming and shaming' - that is publicizing a country's human rights violations and calling for reform. Similarly, the Human Rights Council (as previously the United Nations Commission on Human Rights) provides an international forum in which other governments (as opposed to independent treaty bodies) 'name and shame' through yearly resolutions. Within these resolutions, individual countries are singled out and publicly criticized for failing to uphold international human rights standards. ${ }^{13}$ This strategy of 'naming and shaming' perpetrators of human rights abuses is often employed by NGOs and the news media as well. Theoretically, this strategy is believed to negatively affect a State's reputation for 'good behavior'

11 Ibid., art. 44(6); Migrant Workers Convention, 1990 (n 6), art. 73(4).

12 See, for example, Convention on the Rights of the Child, 1989 (n 6), art. 45(b).

13 James Lebovic/Erik Voeten, 'The Politics of Shame: The Condemnation of Country Human Rights Practices in the UNCHR', International Studies Quarterly 50 (2006), 861-888. 
internationally ${ }^{14}$ or increase social pressures to comply with human rights treaties. ${ }^{15}$ However, its effectiveness in improving compliance is questionable. For example, Emilie Hafner-Burton found that global 'naming and shaming' is often followed by a continuation of or increase in some human rights violations, even as other types of violations (typically those most visible) are reduced. ${ }^{16}$

Just as transparency and human rights appear to be mutually reinforcing at the international level, at the domestic level they seem to go hand in hand as synergetic means to promote democratic consolidation, development and good governance generally. And in fact, over the past three decades, the adoption of access-to-information laws has increased dramatically, ${ }^{17}$ matched if not surpassed by the proliferation of human rights legislation and institutions. ${ }^{18}$ Most domestic theories of compliance with international law also rely on the availability of information about government activities and legal obligations. For example, Beth Simmons argues that knowledge that one's government is publicly committed to comply with an international human rights treaty raises the expectations of domestic groups that they can legitimately demand compliance with such treaties. ${ }^{19}$ Xinyuan Dai hypothesizes that information produced by international bodies can inform domestic audiences about the activities of their governments, and inform judgments about whether a government has complied with its international legal obligations. This information allows domestic constituencies to apply electoral pressure to their government in order to hold them accountable to the law. ${ }^{20}$

We recognize that there are a number of ways to measure human rights transparency, both domestically and internationally. Nevertheless,

${ }^{14}$ Robert Keohane, 'International Relations and International Law: Two Optics', Harvard International Law Journal 38 (1997), 487-502; Andrew Guzman, 'A Compliance-Based Theory of International Law', California Law Review 90 (2002), 1823-1887.

15 Thomas Risse/Kathryn Sikkink, 'The Socialization of International Human Rights Norms into Domestic Practices: Introduction', in Thomas Risse/Stephen Ropp/ Kathryn Sikkinkn (eds.), The Power of Human Rights: International Norms and Domestic Change (New York: Cambridge University Press, 1999), 1-38, 15; Ryan Goodman/Derek Jinks, 'How to Influence States: Socialization and International Human Rights Law', Duke Law Journal 54 (2004), 621-703.

16 Emilie Hafner-Burton, 'Sticks and Stones: Naming and Shaming the Human Rights Enforcement Problem', International Organization 62 (2008), 689-716.

17 Ackerman/Sandoval-Ballesteros, 'Freedom of Information Laws' 2006 (n 1).

18 Simmons, Mobilizing for Human Rights 2009 (n 4), 57-64.

19 Simmons, Mobilizing for Human Rights 2009 (n 4).

${ }^{20}$ Dai, International Institutions and National Policies 2007 (n 4). 
the ultimate goal of international human rights treaties is and should be human rights transparency to a State's population, so that citizens themselves may be provided with the means to further their own human rights. While transparency to international organizations or treaty bodies may be important in encouraging compliance, this chapter focuses on the provision of human rights information to a State's population. A number of institutions may be responsible for providing such information, but this responsibility increasingly has fallen to NHRIs, which we argue have the potential to contribute significantly to transparency regarding human rights law, policies, practices and remedies. Our empirical focus in this chapter is therefore on the diffusion of these institutions around the world, as well as their potential to shed light on these policies to a broad audience, both at home and abroad.

\section{The Role of NHRIs in Human Rights Compliance}

A 'national human rights institution' refers broadly to 'a body which is established by a government under the constitution, or by law or decree, the functions of which are specifically designed in terms of the promotion and protection of human rights'. ${ }^{21}$ Originating in western European and Commonwealth countries, NHRIs spread throughout southern Europe, Latin America, central and eastern Europe during the 1980s and 1990s. More recently, these institutional forms have proliferated throughout Asia and the Middle East. According to our estimates, 144 countries have established some type of a national human rights institution (see Figure 10.1). ${ }^{22}$

The term 'national human rights institution' encompasses a range of governmental bodies with human rights mandates, and in fact there is still considerable debate over the definition of an NHRI. ${ }^{23}$ The three primary 'models' of an NHRI are the classical ombudsman model; the

21 UN, National Human Rights Institutions: A Handbook on the Establishment and Strengthening of National Institutions for the Promotion and Protection of Human Rights (New York: United Nations, 1995), 6.

22 These estimates are based on lists of NHRIs found within existing scholarship or provided by the International Coordinating Committee of NHRIs. In addition, for each of the 199 countries we examined, we independently conducted extensive web searches for any mention of an NHRI not included within the above lists.

23 Ryan Goodman/Thomas Pegram, 'National Human Rights Institutions, State Conformity, and Social Change', in Ryan Goodman/Thomas Pegram (eds.), Human Rights, State Compliance and Social Change: Assessing National Human Rights Institutions (New York: Cambridge University Press, 2012), 1-28, 6-11. 


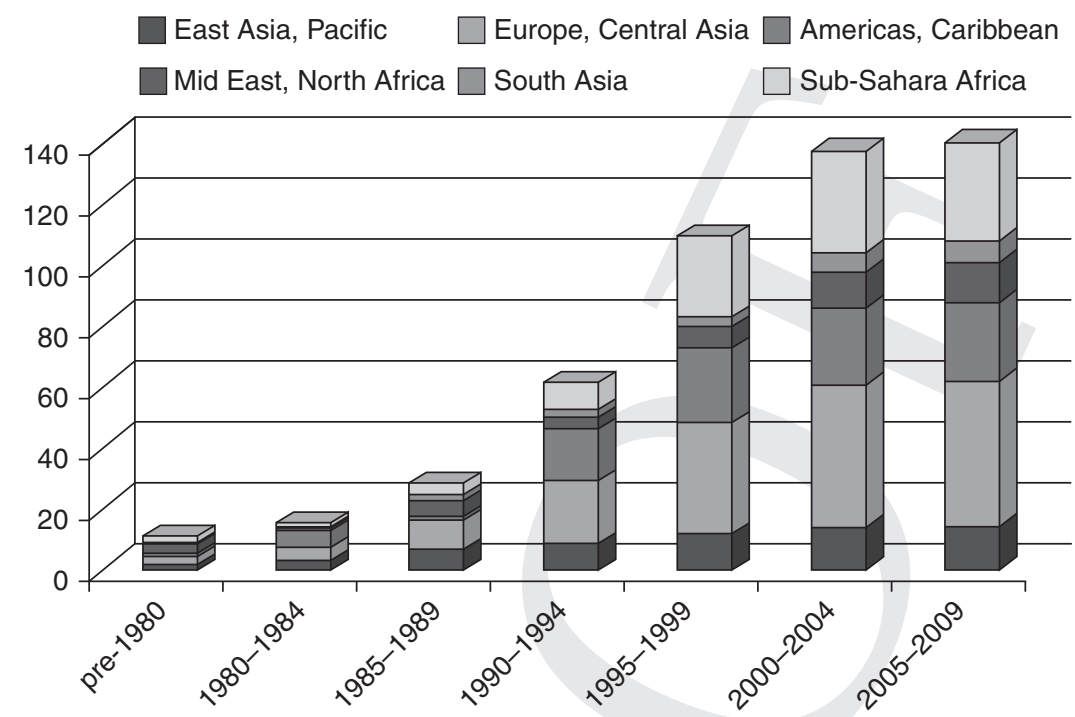

Figure 10.1 Number of National Human Rights Institutes World-wide by Region

national human rights commission model; and a hybrid model. The ombudsman model consists of a single member (the ombudsman) and staff, with a mandate typically covering procedural irregularities in public administration, ethnic and gender discrimination and children's rights. The national human rights commission model is a multi-member institution with a broad mandate to monitor and promote human rights, and in some countries includes the authority to investigative individual complaints. Lastly, the hybrid model, often in the form of a Human Rights Ombudsman Office, combines aspects of the ombudsman and commission models and deals with both human rights and public administration. $^{24}$

24 Jeong-Woo Koo/Francisco O. Ramirez, 'National Incorporation of Global Human Rights: Worldwide Expansion of National Human Rights Institutions, 1966-2004', Social Forces 87 (2009), 1321-1354; International Council on Human Rights Policy, Performance and Legitimacy: National Human Rights Institutions (Versoix: International Council for Human Rights Policy, 2nd edn, 2004); but see Leonard F. M. Besselink, 'Types of National Institutions for the Protection of Human Rights and Ombudsman Institutions: An Overview of Legal and Institutional Issues', in Kamal Hossain et al. (eds.), Human Rights Commissions and Ombudsman Offices (London: Kluwer Law International, 2001), 157-165. 
Serious international cooperation regarding NHRIs really began in the 1990s, with the adoption of the Paris Principles by a group of NHRIs in 1991. The Paris Principles establish general international standards on the mandate and structure of NHRIs, and were later endorsed by the UN Office of the High Commissioner for Human Rights (OHCHR) and the UN General Assembly. ${ }^{25}$ In 1994, NHRIs established their own network in the form of the International Coordinating Committee of National Human Rights Institutions, charged with organizing and overseeing all international and regional connections. The International Coordinating Committee and the OHCHR have provided some definitional convergence by establishing an accreditation process for NHRIs, based on the institution's compliance with the Paris Principles. ${ }^{26}$ Although States are often encouraged to establish an NHRI, there currently exists no international legal obligation for them to do so.

According to the Paris Principles, NHRIs are government-initiated and financed institutions that are supposed to remain independent of the government and other actors. While all are ostensibly designed to promote human rights, NHRIs display considerable variation in their official functions. These functions typically include: reviewing proposed and existing legislation for compliance with 'fundamental principles of human rights'; ${ }^{27}$ monitoring international treaty implementation; producing reports on a government's human rights practices; providing training and research opportunities to various governmental and nongovernmental actors; and assisting with individual complaints.

Not all NHRIs have explicit jurisdiction over international human rights, particularly within countries that have historically enjoyed strong domestic protections or that prefer domestic to international mechanisms. Yet even for those that do not have an explicit international mandate, NHRIs are often tasked with helping to ensure implementation of and compliance with the human rights conventions a State has ratified. In fact, the UN encourages the establishment of NHRIs precisely because these institutions are believed to provide a central mechanism

25 UNGA, National Institutions for the Promotion and Protection of Human Rights, A/RES/48/134, 20 December 1993, annex: Principles Relating to the Status of National Institutions (Paris Principles).

26 The Paris Principles include, inter alia: operation independent from government; membership that broadly reflects societal composition; incorporation into legislation; and cooperation with civil society. For a description of the accreditation procedure, see: http://nhri.ohchr.org/EN/AboutUs/ICCAccreditation/Pages/default.aspx.

27 UNGA, Paris Principles, 1993 (n 25), art. 3(i). 
through which international human rights norms can be implemented at the domestic level. ${ }^{28}$ They are viewed as providing the 'practical link between international standards and their concrete application' ${ }^{29}$ and have even been permitted to participate in relevant meetings of the UN Commission on Human Rights and the Human Rights Council. ${ }^{30}$

One way in which NHRIs contribute to the implementation of international human rights is by influencing the content of domestic human rights legislation, itself often inspired by ratification of international human rights conventions. ${ }^{31}$ The majority of NHRIs are mandated to advise governments on the compatibility of proposed or existing legislation with international standards. In addition, NHRIs often apply international human rights standards in their monitoring activities, particularly in the drafting of annual reports and in their handling of individual complaints and cases. They are also increasingly viewed as important sources of information regarding States' periodic reports submitted to international treaty bodies, and many even submit their own 'shadow reports' to these bodies.

The promotion and education function of NHRIs is perhaps most relevant to a government's human rights transparency. The educational work of NHRIs covers a broad range of activities, such as public education on human rights, public awareness campaigns, media work, and training State officials about the human rights standards with which they must comply. This public education and awareness function is fundamentally about communicating to the public in simple terms what human rights are and what mechanisms are available to protect them. It also entails publicizing the steps a country has taken to implement and

28 UNGA, National Institutions for the Promotion and Protection of Human Rights: Report of the Secretary-General, A/64/320, 24 August 2009; UNGA, The Role of the Ombudsman, Mediator and Other National Human Rights Institutions in the Promotion and Protection of Human Rights, A/RES/63/169, 20 March 2009; UNGA, National Institutions for the Promotion and Protection of Human Rights, A/RES/63/ 172, 20 March 2009; Goodman/Pegram, 'National Human Rights Institutions' 2012 (n 23), 16-18.

29 UN, Economic and Social Council, Further Promotion and Encouragement of Human Rights and Fundamental Freedoms, Including the Question of the Programme and Methods of Work of the Commission: National Institutions for the Promotion and Protection of Human Rights: Report of the Secretary General Submitted in Accordance with Commission on Human Rights Resolution 1996/50, E/CN.4/1997/41, 5 February 1997.

30 Julie A. Mertus, Human Rights Matters: Local Politics and National Human Rights Institutions (Stanford University Press, 2009), 8.

31 Simmons, Mobilizing for Human Rights 2009 (n 4). 
comply with international human rights obligations. In this way NHRIs remain a central locus for transparency regarding government human rights practices, although many NHRIs face significant challenges in making their services accessible to as many people as possible.

A growing body of scholarship has sought to identify the conditions facilitating the transnational spread of NHRIs. A number of studies find that international institutions - specifically the OHCHR and UN treaty bodies - play an important role in persuading government actors to establish NHRIs. ${ }^{32}$ Global and regional NHRI networks have also been identified as significant actors in explaining the particular form of an NHRI. ${ }^{33}$ Apart from these influential actors, cross-national studies have found some evidence supporting a world polity explanation, according to which countries that are 'more embedded' in 'world culture' are more likely to create an NHRI. ${ }^{34}$ A State's membership in international governmental and NGOs, the number of international human rights conventions it has ratified, and the regional and global density of NHRIs have all been found to help explain the decision to set up this institution. Predictably, democratic countries with few human rights violations are more likely to create an NHRI, though an increasing number of 'partly free' and 'not free' countries are setting up these institutions as well. Income, based on World Bank Gross Domestic Product per capita categories, on the other hand, does not seem to be correlated with NHRI creation. ${ }^{35}$

\section{NHRI Transparency}

The formal establishment of an NHRI does not in and of itself guarantee that this institution will provide information or enhance knowledge about a country's human rights practices and processes. Yet as one of

32 Sonia Cardenas, 'Emerging Global Actors: The United Nations and National Human Rights Institutions', Global Governance 9 (2003), 23-42; Thomas Pegram, 'Diffusion Across Political Systems: The Global Spread of National Human Rights Institutions', Human Rights Quarterly 32 (2010), 729-760; Peter Rosenblum, 'Tainted Origins and Uncertain Outcomes: Evaluating NHRIs', in Goodman/Pegram, Human Rights, State Compliance and Social Change 2012 (n 23), 297-323.

33 Goodman/Pegram, Human Rights, State Compliance and Social Change 2012 (n 23); Linda C. Reif, 'The Shifting Boundaries of NHRI Definition in the International System', in Goodman/Pegram, Human Rights, State Compliance and Social Change 2012 (n 23), 52-73.

34 Koo/Ramirez, 'National Incorporation of Global Human Rights' 2009 (n 24).

35 Ibid.; Pegram, 'Diffusion Across Political Systems' 2010 (n 32). 
the few governmental institutions explicitly charged with human rights promotion and protection, an NHRI is the institution where we would expect to see the most transparency regarding a State's human rights practices. Perhaps more importantly, the explicit human rights mandate of an NHRI implies that it is the body to which citizens themselves would first look when seeking information about their human rights and the mechanisms available to ensure their realization. And in fact, the extent to which an NHRI makes itself accessible to those most vulnerable to human rights violations has been recognized as a critical element in evaluating the performance and legitimacy of the institution. ${ }^{36}$

Over the past few decades, advances in information and communication technologies have fundamentally changed how governments provide information and services to their citizens. The broader global movement toward e-government ${ }^{37}$ suggests that one measure of a government's transparency is the amount of information it provides on its own websites. And with the dramatic increase over the past decade in internet penetration worldwide, one of the primary methods through which citizens now access information is through the internet, which many claim has enhanced the power of non-State actors. ${ }^{38}$ Admittedly, improvements in telecommunication infrastructure and e-government depend considerably on sufficient resources to provide affordable access. While developed countries would be expected to rely more on e-government, developing countries have also recognized the centrality of information technology infrastructure and e-government, particularly for attracting economic investment. ${ }^{39}$ Empirical assessments of levels of e-government have confirmed that the dissemination of government information via the internet is not simply a developed country phenomenon. ${ }^{40}$

${ }^{36}$ International Council on Human Rights Policy, Performance and Legitimacy 2004 (n 24).

37 Darrell M. West, 'Global E-Government, 2007', August 2007, available at: www.inside politics.org.

38 Ronald Deibert, 'International Plug'n'Play? Citizen Activism, the Internet, and Global Public Policy', International Studies Perspectives 1 (2004), 255-272; Craig Warkentin/ Karen Mingst, 'International Institutions, the State and Global Civil Society in the Age of the World Wide Web', Global Governance 6 (2000), 237-257.

39 Pippa Norris, Digital Divide: Civic Engagement, Information Poverty and the Internet Worldwide (Cambridge University Press, 2001).

${ }^{40}$ Darrel M. West, 'E-Government and the Transformation of Service Delivery and Citizen Attitudes', Public Administration Review 64 (2004), 15-27; West, 'Global EGovernment' 2007 (n 37). 
Table 10.1 National Human Rights Institutes (NHRIs) and NHRIs with Working Websites, by Region

\begin{tabular}{|c|c|c|c|c|}
\hline \multirow[b]{2}{*}{ Region } & \multicolumn{2}{|r|}{ NHRIs } & \multicolumn{2}{|c|}{ Working Websites } \\
\hline & Number & $\begin{array}{l}\% \text { countries } \\
\text { in region }\end{array}$ & Number & $\begin{array}{l}\% \text { NHRIs } \\
\text { in region }\end{array}$ \\
\hline $\begin{array}{l}\text { Americas, } \\
\text { Caribbean }\end{array}$ & 25 & 67.57 & 21 & 84.00 \\
\hline East Asia, Pacific & 15 & 48.39 & 12 & 80.00 \\
\hline Europe, Central Asia & 46 & 85.19 & 42 & 91.30 \\
\hline $\begin{array}{l}\text { Middle East, North } \\
\text { Africa }\end{array}$ & 13 & 61.91 & 9 & 69.23 \\
\hline South Asia & 7 & 87.50 & 7 & 100.00 \\
\hline Sub-Saharan Africa & 34 & 72.34 & 15 & 44.12 \\
\hline
\end{tabular}

Source: Authors' database, based on accessing each website during August-September 2011.

As of 2011, most NHRIs do have websites (see Table 10.1). South Asia has the highest proportion of NHRIs of any region in the world, and all have working websites. East Asia has the smallest proportion of NHRIs (slightly less than half of the countries in the region at this point), but most do have working websites. In absolute numbers, Europe and central Asia have the largest number of working NHRI websites, with forty-two. In sub-Saharan Africa, on the other hand, operative NHRI websites were much less common: fourteen countries with NHRIs had no web-presence at all, and another five had web-addresses that led nowhere.

Table 10.2 is a more systematic effort to analyze the correlates of transparency as indicated by the existence of a working website. It presents the findings of a multivariate logit model, which expresses the correlation (if any) between various explanatory variables (listed in the first column on the left of the table) and whether a country has a working website, a non-functioning web address or no website at all. The potential correlates we test are proxies for governance arrangements and capacities, human rights practices, income per capita and internet technical capacity. The results are quite strong and striking. They are also just as one might expect. Countries that are well and transparently governed 
Table 10.2 NHRIs and Transparency: Correlates of a Working Website (ordered logit coefficients; probabilities)

\begin{tabular}{|c|c|c|c|c|c|}
\hline & Model 1 & Model 2 & Model 3 & Model 4 & Model 5 \\
\hline $\begin{array}{l}\text { Government Effectiveness } \\
\quad(2000)\end{array}$ & $\begin{array}{l}1.105^{* * *} \\
(\mathrm{p}=.001)\end{array}$ & - & - & - & - \\
\hline Rule of Law & - & $\begin{array}{l}.964^{* * *} \\
(\mathrm{p}=.007)\end{array}$ & $\begin{array}{l}1.59^{* * *} \\
(p=.000)\end{array}$ & $\begin{array}{l}1.16^{* *} \\
(\mathrm{p}=.015)\end{array}$ & $\begin{array}{l}.972^{\star *} \\
(\mathrm{p}=.042)\end{array}$ \\
\hline $\begin{array}{l}\text { Democracy }(2005-10 \\
\text { average) }\end{array}$ & $\begin{array}{l}.099^{\star *} \\
(\mathrm{p}=.024)\end{array}$ & $\begin{array}{l}.118^{* * *} \\
(\mathrm{p}=.010)\end{array}$ & $\begin{array}{l}.159^{* * *} \\
(p=.000)\end{array}$ & $\begin{array}{l}.176^{* * *} \\
(\mathrm{p}=.000)\end{array}$ & $\begin{array}{l}.164^{\star * *} \\
(\mathrm{p}=.001)\end{array}$ \\
\hline NHRI age (logged) & $\begin{array}{l}1.04^{\star} \\
(\mathrm{p}=.075)\end{array}$ & $\begin{array}{l}1.15^{\star *} \\
(\mathrm{p}=.05)\end{array}$ & $\begin{array}{l}1.32^{* *} \\
(\mathrm{p}=.011)\end{array}$ & $\begin{array}{l}1.29^{* *} \\
(\mathrm{p}=.017)\end{array}$ & $\begin{array}{l}1.32^{\star *} \\
(\mathrm{p}=.017)\end{array}$ \\
\hline $\begin{array}{l}\text { Physical integrity index } \\
\text { (2000) }\end{array}$ & - & - & $\begin{array}{l}-.512^{\star \star} \\
(\mathrm{p}=.032)\end{array}$ & $\begin{array}{l}-.597^{\star *} \\
(\mathrm{p}=.015)\end{array}$ & $\begin{array}{l}-.600^{\star *} \\
(\mathrm{p}=.035)\end{array}$ \\
\hline Income level (World Bank) & - & - & - & $\begin{array}{l}.751^{\star *} \\
(\mathrm{p}=.015)\end{array}$ & $\begin{array}{l}.622^{\star} \\
(p=.051)\end{array}$ \\
\hline $\begin{array}{l}\text { Internet penetration } \\
\text { in country }\end{array}$ & - & - & - & - & $\begin{array}{l}.026 \\
(p=.420)\end{array}$ \\
\hline Observations & 112 & 112 & 112 & 112 & 112 \\
\hline Pseudo R2 & .17 & .17 & .22 & .26 & .26 \\
\hline
\end{tabular}

Note:

${ }^{*}=$ significant at .10 level;

${ }^{* *}=$ significant at .05 level;

$* * *=$ significant at .01 level.

Dependent variable: $0=$ no website; $1=$ web address, but link does not work or does not lead to an operative NHRI website; $2=$ web address leads to an operative NHRI website

Source of dependent variable: Authors' database, based on accessing each website during August-September 2011.

according to a variety of measures are also more likely to have working NHRI websites. (The sample here covers only those countries with NHRIs; those without are dropped.) Working NHRI websites are correlated with government effectiveness and rule of law (as measured by the World Governance Indicators and the World Bank). Note however that we do not include these variables in the same models because they are highly correlated (with a Pearson's correlation coefficient of .88). Furthermore, countries that were more democratic on average between 2005 and 2010 were much more likely to have NHRIs with working 
websites. The older the NHRI (as measured by the number of years, logged), the more likely it was to have a working website. Also unsurprisingly, NHRIs in wealthier countries were more likely to have working NHRI websites. There are, however, two surprising results in this table. Once we control for other governance factors, it appears to be the case that the better a countries human rights practices, ${ }^{41}$ the less likely it is to have an NHRI website. This may reflect a calculation that good rights practices make this form of transparency somewhat unnecessary. It is also surprising that our proxy for technical capacity - average internet penetration (internet connections per 1000 population) - has practically no relationship to the existence of a working NHRI website. It seems more likely that transparency with respect to human rights as measured by the existence of a website is correlated with governance indicators rather than technical information technology capacity.

Of course it is not enough just to have a website. E-government has the potential to increase transparency only to the extent that citizens and international governmental and NGOs are able to access information on a State's human rights practices on a timely basis. ${ }^{42}$ And a website only enhances transparency to the extent that it helps a rights holder know what his or her rights are and how to go about ensuring their realization. This points to a number of specific elements we would expect NHRI websites to provide if they were fully transparent. First, we would expect an NHRI to help citizens understand their legal rights under international and domestic law. Second, a fully transparent NHRI would present clear and unbiased information on a State's human rights practices, including not only the good news about efforts being made, but also the bad news about continuing problems and weaknesses. ${ }^{43}$ Third, a transparent NHRI should provide instructions on how citizens can submit complaints or communications to domestic or international treaty bodies, or offer to help in this regard.

41 Human rights practices are measured by the Physical Integrity Index within the Cingranelli-Richards (CIRI) Human Rights Data Project, which summarizes government compliance with human rights relating to torture, extrajudicial killing, political imprisonment and disappearance.

42 Thomas Barnebeck Andersen, 'E-Government as an Anti-Corruption Strategy', Information Economics and Policy 21 (2009), 201-210.

43 While we recognize the importance of accuracy of information provided by NHRIs, our measures of transparency only capture the amount and to some extent the quality of information provided, without evaluating accuracy. We believe this constitutes a sufficient first step in measuring NHRI transparency. 


\subsection{Transparency about the Law}

In terms of international human rights, actual NHRI websites display some interesting patterns. Of the 106 NHRIs with working websites, only 19 make no reference to international law at all. Thirty-two provide a special section devoted to explaining international legal obligations, with the remaining fifty-five making at least some reference to international law. Surprisingly only nine NHRI websites provide what can be considered a 'lay definition' of the protections afforded by international human rights law.

In contrast to general references to international human rights, fortyfour NHRI websites provide no indication of the specific conventions the State has ratified. Of those that do, thirty-four provide a list of ratified treaties that appears exhaustive, while twenty-eight mention some ratified treaties but do not provide a systematic list. Fifty-nine NHRI websites provide no working links to treaty texts, while forty-seven do.

Why are some NHRIs so clear about the nature of international legal obligations, while others barely mention international human rights law? One possibility is that NHRIs rely more explicitly on international legal instruments when domestic legal structures and protections are weak. However, there appears to be very little evidence for this 'substitution' proposition. There is very little difference among countries that have been stable democracies since World War II (or independence), countries that have never been democratic, and all others in various stages and directions of regime transition in this regard. We created an index (ranging from 0 to 8 ) that combines the above transparency dimensions to capture the extent to which NHRI websites are transparent about international legal obligations, but find very little difference on this measure across regime types (see Table 10.3).

By comparison, many more NHRIs focus on domestic human rights law. Of the 106 NHRIs with working websites, all of them mention domestic human rights law (statutory or constitutional) though only 47 provide an accessible layperson explanation of these protections. Eighty NHRIs provide working links to the actual texts of these laws. Surprisingly, transparency regarding domestic law is not correlated in any straightforward way with regime type. We created a measure of domestic legal transparency analogous to the international measure above, and Table 10.4 shows that there is practically no relationship between the regime type of the country that is home to the NHRI and the extent to which their website is clear about domestic human rights law. 


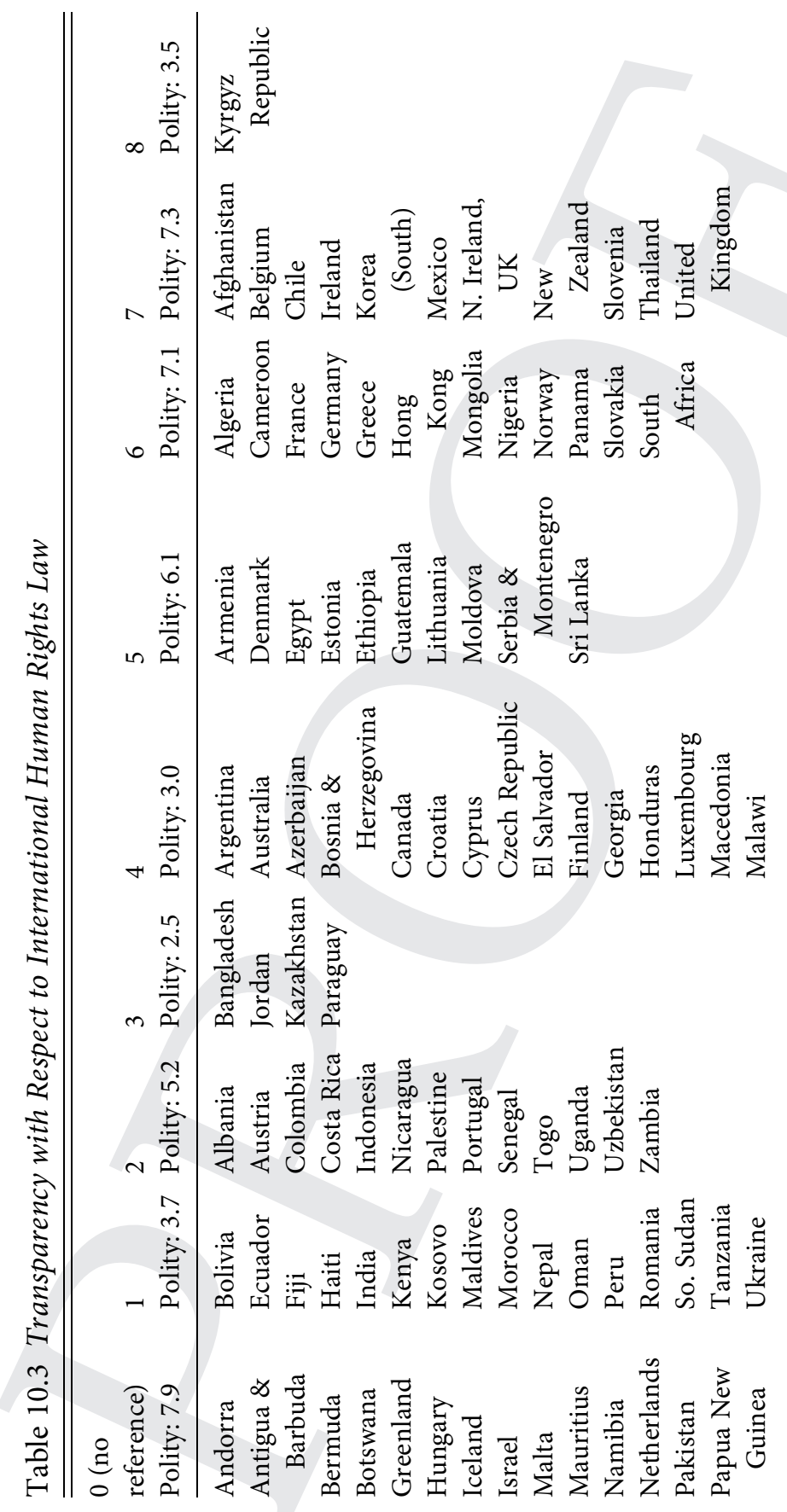




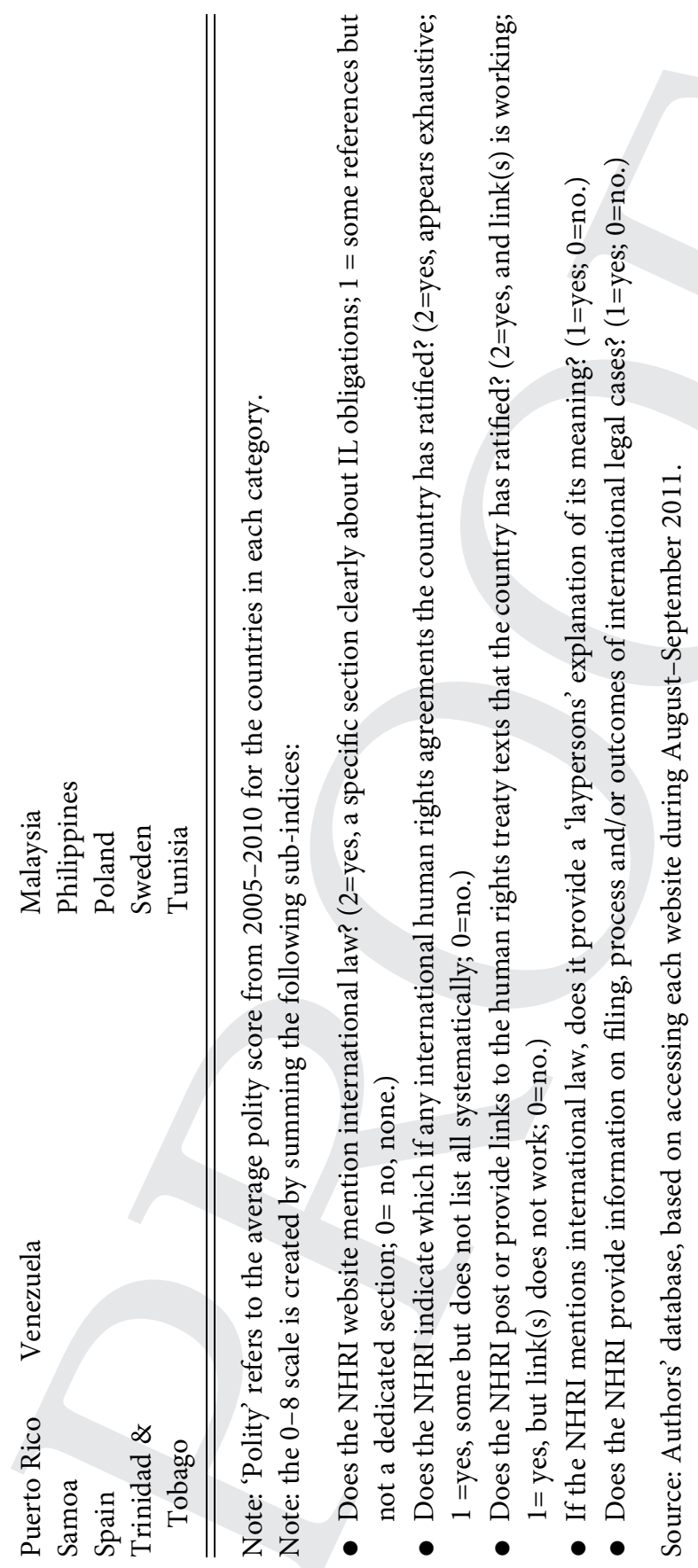




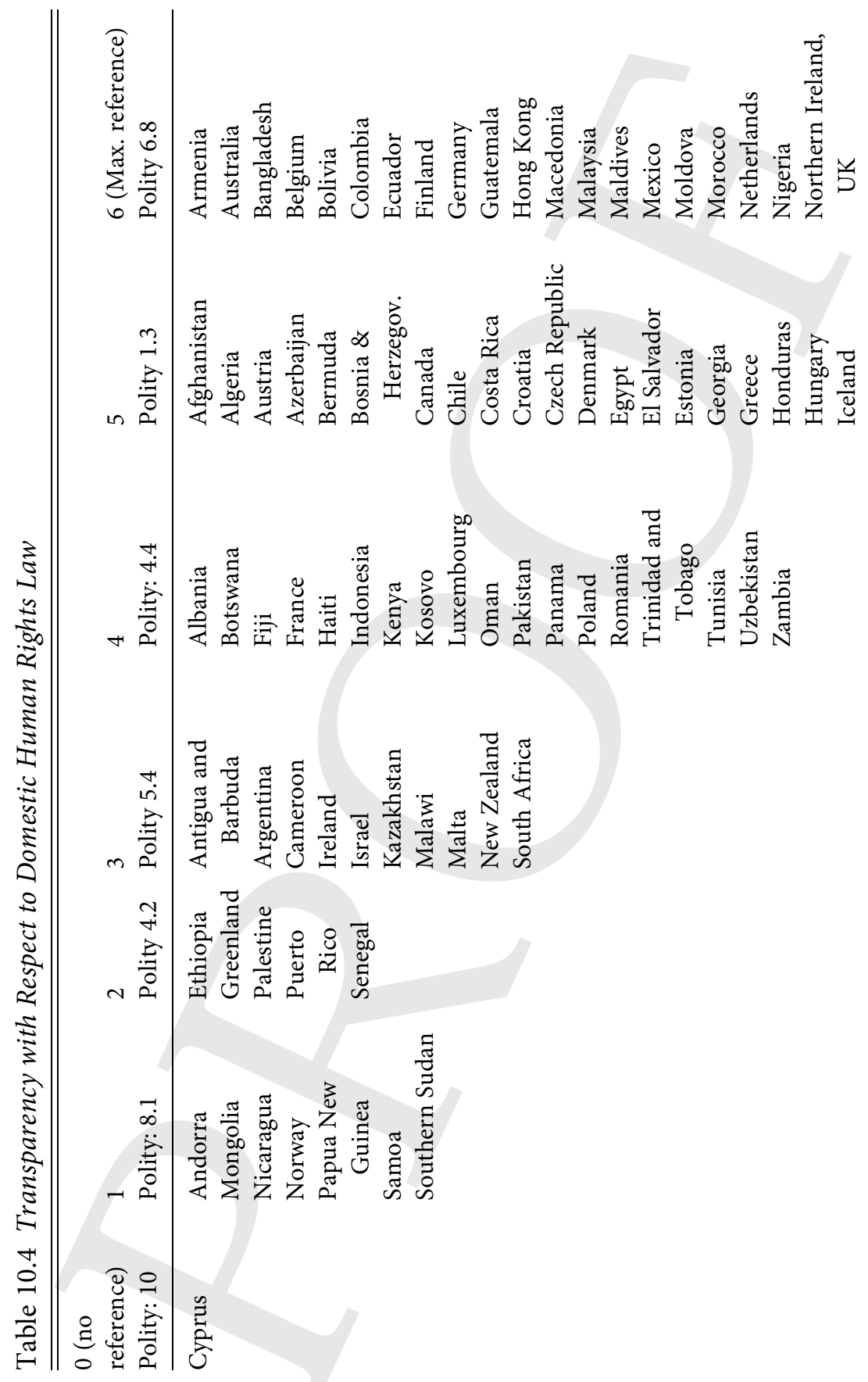



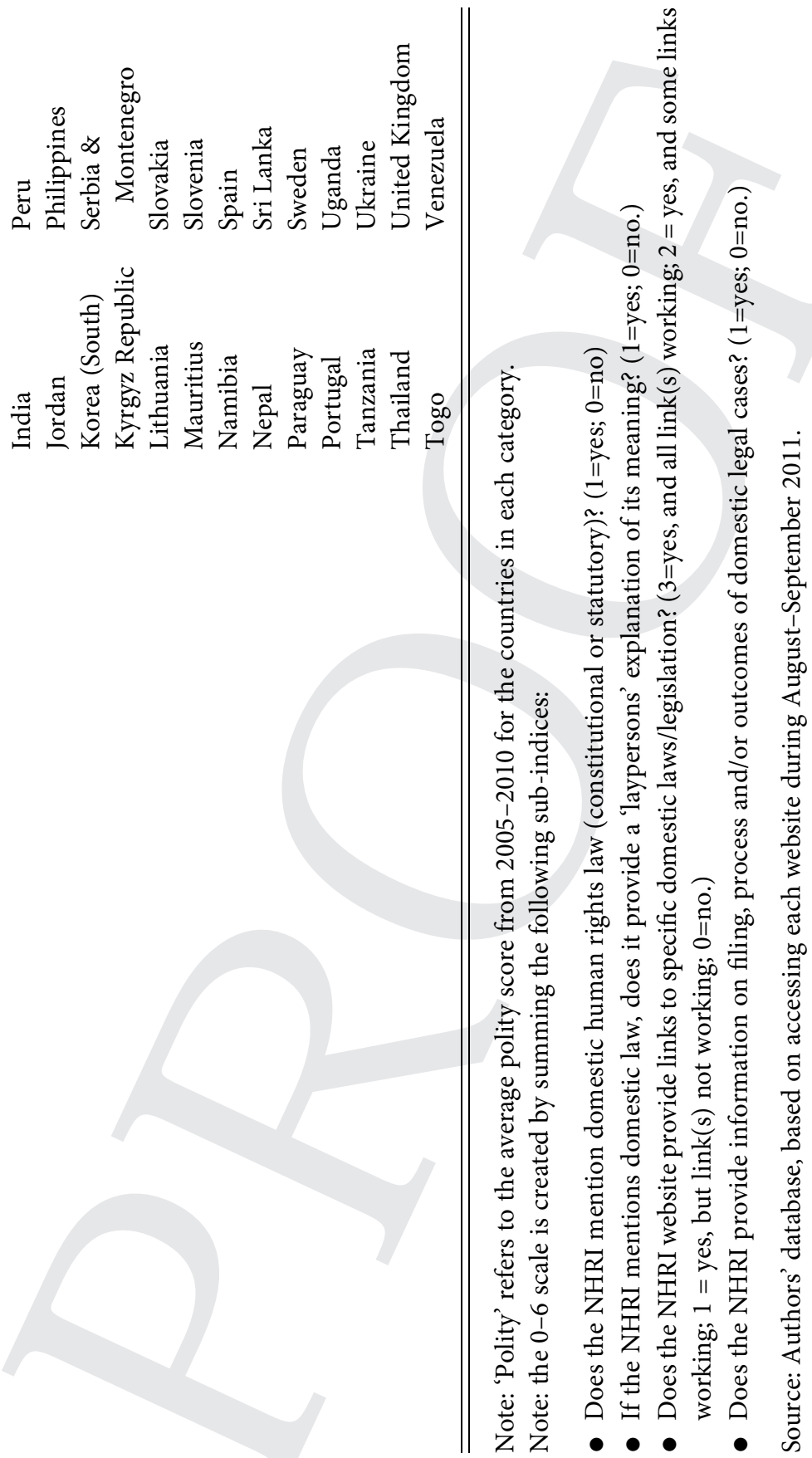
A more systematic analysis of the data confirms that the democratic nature of the regime that is home to the NHRI does not predict a high degree of transparency with respect to either international or domestic law. Table 10.5 displays the results of a regression analysis of the correlates of legal transparency. The dependent variables in this table are the domestic law transparency score, the international law transparency score, the ratio of the latter to the former, and the total (the sum of the two scores). The average degree of democracy between 2005 and 2010 is not correlated with any of these. Similarly, transparency is not correlated with a country's democracy score for 2010, the variance in democratic governance between 2005 and 2010, or whether a country has been a stable democracy, in transition or a stable autocracy since World War II.

The two factors that seem most consistently associated with legal transparency are the age of the NHRI and the income level of the country in which it is situated. Older NHRIs are much less likely to be transparent about international legal obligations, and legal obligations in general. The younger the NHRI, the more likely it is to provide clear, accessible and thorough information about international legal obligations. Note that there is no relationship between NHRI age and domestic legal transparency alone, however. Furthermore, the higher the income level of the country home to the NHRI, the more likely the it is to thoroughly and transparently discuss human rights law, particularly international human rights law.

\subsection{Transparency about Practices}

A key aspect of transparency is that citizens are able to access information about their government's policies, and - even more essential - their actual practices. In the human rights area, access to information about the measures governments are taking to improve rights, as well as their shortcomings, is important if citizens are to effectively hold their government accountable. Since one of the primary purposes of NHRIs is to promote human rights, transparency should facilitate access to information about how well a government implements laws and respects the rights of its people in practice.

Transparent NHRIs should be willing to post neutral and accurate reports of their human rights record on their website. But in contrast to the large number of NHRIs that are reasonably transparent about the law, few offer performance-based information on their websites. We found that 92 of the 106 NHRIs with working websites do not mention 
Table 10.5 Correlates of Legal Transparency

Sample: NHRIs with websites

Regression Coefficients (probability)

\begin{tabular}{|c|c|c|c|c|}
\hline & $\begin{array}{l}\text { Domestic } \\
\text { law } \\
\text { transparency }\end{array}$ & $\begin{array}{l}\text { International } \\
\text { law } \\
\text { transparency }\end{array}$ & $\begin{array}{l}\text { Ratio of } \\
\text { international to } \\
\text { domestic } \\
\text { transparency }\end{array}$ & $\begin{array}{l}\text { Total legal } \\
\text { transparency }\end{array}$ \\
\hline $\begin{array}{l}\text { International } \\
\text { legal } \\
\text { Transparency }\end{array}$ & $\begin{array}{l}.209^{\star *} \\
(\mathrm{p}=.011)\end{array}$ & - & - & _ \\
\hline $\begin{array}{l}\text { Domestic legal } \\
\text { Transparency }\end{array}$ & - & $\begin{array}{l}.328^{\star *} \\
(\mathrm{p}=.011)\end{array}$ & - & - \\
\hline Income level & $\begin{array}{l}.442 \\
(\mathrm{p}=.102)\end{array}$ & $\begin{array}{l}-.009 \\
(p=.980)\end{array}$ & $\begin{array}{l}.005 \\
(p=.963)\end{array}$ & $\begin{array}{l}.620 \\
(p=.214)\end{array}$ \\
\hline $\begin{array}{l}\text { Physical } \\
\text { integrity } \\
\text { index (2009) }\end{array}$ & $\begin{array}{l}-.377^{\star * *} \\
(\mathrm{p}=.003)\end{array}$ & $\begin{array}{l}-.164 \\
(\mathrm{p}=.305)\end{array}$ & $\begin{array}{l}-.011 \\
(\mathrm{p}=.825)\end{array}$ & $\begin{array}{l}-.751^{\star * *} \\
(\mathrm{p}=.001)\end{array}$ \\
\hline $\begin{array}{l}\text { Internet } \\
\text { penetration }\end{array}$ & $\begin{array}{l}.030^{* *} \\
(\mathrm{p}=.015)\end{array}$ & $\begin{array}{l}.005 \\
(p=.808)\end{array}$ & $\begin{array}{l}-.003 \\
(\mathrm{p}=.592)\end{array}$ & $\begin{array}{l}.049^{\star} \\
(\mathrm{p}=.080)\end{array}$ \\
\hline Rule of law & $\begin{array}{l}-.434 \\
(\mathrm{p}=.213)\end{array}$ & $\begin{array}{l}.662 \\
(p=.129)\end{array}$ & $\begin{array}{l}.161 \\
(p=.260)\end{array}$ & $\begin{array}{l}.241 \\
(p=.705)\end{array}$ \\
\hline $\begin{array}{l}\text { Average } \\
\text { democracy } \\
\text { level } \\
(2005-2010)\end{array}$ & $\begin{array}{l}.005 \\
(p=.917)\end{array}$ & $\begin{array}{l}.031 \\
(\mathrm{p}=.487)\end{array}$ & $\begin{array}{l}-.007 \\
(\mathrm{p}=.689)\end{array}$ & $\begin{array}{l}.048 \\
(p=.577)\end{array}$ \\
\hline $\begin{array}{l}\text { Ratification of } \\
\text { human rights } \\
\text { treaties }\end{array}$ & $\begin{array}{l}2.60^{\star} \\
(p=.072)\end{array}$ & $\begin{array}{l}2.20 \\
(p=.226)\end{array}$ & $\begin{array}{l}.383 \\
(p=.514)\end{array}$ & $\begin{array}{l}6.56^{\star * *} \\
(\mathrm{p}=.013)\end{array}$ \\
\hline NHRI age (log) & $\begin{array}{l}.475 \\
(p=.267)\end{array}$ & $\begin{array}{l}-1.36^{\star * *} \\
(\mathrm{p}=.001)\end{array}$ & $\begin{array}{l}-.378^{\star *} \\
(\mathrm{p}=.022)\end{array}$ & $\begin{array}{l}-1.09 \\
(p=.157)\end{array}$ \\
\hline Number of Obs & 101 & 101 & 86 & 101 \\
\hline Adjusted R2 & .30 & .17 & .09 & .20 \\
\hline
\end{tabular}

Note:

${ }^{*}=$ significant at .10 level;

${ }^{* *}=$ significant at .05 level;

${ }^{* * *}=$ significant at .01 level.

Source of dependent variables: Authors' database, based on accessing each website during August-September 2011. (See notes to Tables 10.2 and 10.3 above.) 
their periodic reports to international human rights bodies. Six mentioned these reports, but did not provide working links so that private citizens could access them. Eight NHRIs do post these reports, and the links work (Germany, Sweden, France, Greece, Ireland, New Zealand, Maldives and South Korea). This kind of transparency does seem to be the special preserve of the most democratic countries: the average polity score for those that provided working access to their country reports was 9.5, while that for those with broken links was significantly lower (-2.8). Countries that do not mention the reports at all had an average polity score of 4.4. The eight countries that posted country reports are also the only ones that provide links to the oversight committees' responses to these reports. And only Northern Ireland, Denmark, Germany, Sweden, New Zealand and the Maldives post 'shadow reports' by non-governmental groups that provide an independent assessment of government policies and practices. Furthermore, only seventeen countries provide information on international legal challenges to a State's human rights practices.

\subsection{Transparency about How to Lodge a Violation Complaint}

One of the primary reasons transparency is important is that it enhances the possibility that people will be able to act to protect their rights and interests. NHRIs are not only valuable institutions for promoting knowledge about rights and practices, but also for assisting citizens in understanding their options if they feel their rights have been somehow violated. This can include instructions on how to lodge a complaint with the NHRI or other appropriate national bodies, as well as how to submit individual communications to international treaty bodies. We therefore examined all NHRI websites in search of evidence that they informed citizens of available steps - both domestic and international to have the (alleged) violation addressed, considering both legal (judicial) as well as non-legal (mediation, investigation) options. We found that seventy-one NHRI websites made some mention of steps individuals could take if they felt their rights had been violated; thirty-five gave no guidance whatsoever.

It is clear that NHRIs are much more focused on domestic rather than international options for addressing alleged rights violations. Fully sixtynine NHRI websites explain (with varying degree of clarity and completeness) what non-judicial steps individuals can take to have rights' issues addressed. Another thirty explain what citizens can do to pursue 
Answered e-mail $\square$ Did not answer e-mail

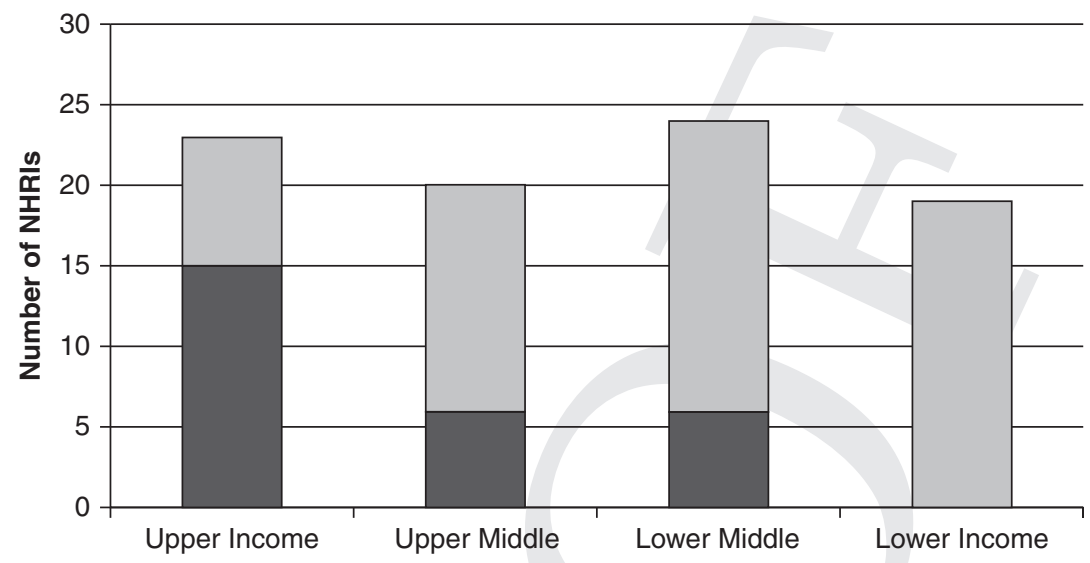

Figure 10.2 NHRI E-mail Responsiveness, by Country's Income Level

their rights through the courts or other legal means. Few NHRIs reference international options, however. Only the websites of Cameroon and Thailand mention non-legal international options, such as contacting international NGOs or the UN OHCHR, while only Slovakia's NHRI mentions international legal options individuals may pursue on its website.

No matter how clear an NHRI tries to be in explaining available options for lodging complaints about rights violations, in many cases citizens will need further clarification or seek assistance in this process. As a final test of transparency in pursuing remedies for rights violations, we e-mailed every NHRI that had an e-mail contact address with the subject heading 'rights question' and the following message from a Yahoo! domain: '[i]f I feel my rights have been violated, how does the complaint process proceed? [signed] C.s.D'. First and foremost, we coded whether the NHRI answered this simple but vague question. Only thirty-three NHRIs answered within two months; sixty-four did not. Figure 10.2 shows that capacity of the NHRI might explain the likelihood of receiving an answer: the higher the income category of the country, the higher the proportion of e-mails sent resulted in some kind of answer.

Of the thirty-three that responded, seventeen gave a complete and fairly useful answer. Eight said we should have contacted another person or office; four NHRIs responded with an automatic message of a general 
nature; and eight provided us with a personal but very vague answer. To our knowledge, none forwarded our message to another destination; nor did any discourage us from further contact.

\section{Is Transparency Correlated with Better Rights Practices?}

Our final question is whether transparency as measured by the existence and quality of information to which citizens have access matters for actual rights practices. Unfortunately our current data do not allow us to answer this question since we cannot sort out cause and effect. This is especially the case since all of our explanatory variables relating to transparency were measured in the summer and autumn of 2011, while most of the measures available on human rights practices are for the year 2009 at the latest. On the one hand, we cannot explain something observed in 2009 with a 'cause' observed in 2011. On the other hand, many of the websites explored in this research have been up and running for years, and it is at least possible if not likely that some of our measures of legal transparency were in place well before we collected out data. In the absence of a longer time series of data measuring transparency, the most we can do at this point is explore relationships between changes in practices over the past decade and recent measures of transparency. We do this by reporting correlations between recent transparency measures and recent human rights practices, controlling for practices in 2000. It is also important to admit that even in the best of circumstances, transparency - and especially the fairly narrow indicators of transparency we explore in this chapter - is likely to explain only a small fraction of any variance we see in rights practices over the past decade. Compounded with quite crude measures of rights practices themselves, we should not be surprised to see extremely weak correlations between transparency and rights improvements.

This is in fact what we find. Table 10.6 reports a series of models that regress 2009 rights measures on rights measures in 2000 and our various measures of transparency. ${ }^{44}$ For all of these measures, we found no evidence of a positive correlation between the mere existence of an NHRI and a rights improvement. In one case - using a measure of general 'empowerment' that taps into the extent to which citizens are

44 These measures include: the existence of an NHRI; existence of a website; the quality of legal transparency, reporting on government practices and providing an e-mail answer advising about 'what to do if my rights have been violated'. 
Table 10.6 Is Transparency Correlated with Better Rights Practices? Results of OLS regression ('No'=less that 15\% probability that the estimated coefficient is different than zero).

\begin{tabular}{|c|c|c|c|c|c|}
\hline & $\begin{array}{l}\text { Physical } \\
\text { Integrity }\end{array}$ & Torture & $\begin{array}{l}\text { Workers' } \\
\text { rights }\end{array}$ & $\begin{array}{l}\text { Empowerment } \\
\text { (CIRI) }\end{array}$ & $\begin{array}{l}\text { Voice and } \\
\text { Accountability } \\
\text { (World Bank) }\end{array}$ \\
\hline NHRI & No & No & No & $\begin{array}{l}-.467^{\star} \\
(\mathrm{p}=.071)\end{array}$ & No \\
\hline $\begin{array}{l}\text { Given an } \\
\text { NHRI: } \\
\text { website }\end{array}$ & $\begin{array}{l}.225^{\star} \\
(\mathrm{p}=.070)\end{array}$ & $\begin{array}{l}.084 \\
(\mathrm{p}=.124)\end{array}$ & No & No & No \\
\hline $\begin{array}{l}\text { Given NHRI } \\
\text { website: } \\
\text { Legal } \\
\text { transparency }\end{array}$ & No & $\begin{array}{l}.011 \\
(p=.144)\end{array}$ & No & No & No \\
\hline $\begin{array}{l}\text { Given NHRI } \\
\text { website: } \\
\text { reporting }\end{array}$ & No & No & $\begin{array}{l}.052 \\
(p=.129)\end{array}$ & $\begin{array}{l}.187 \\
(\mathrm{p}=.142)\end{array}$ & No \\
\hline $\begin{array}{c}\text { Given NHRI } \\
\text { website: } \\
\text { answering }\end{array}$ & No & No & $\begin{array}{l}.220^{\star} \\
(\mathrm{p}=.055)\end{array}$ & No & $\begin{array}{l}.119 \\
(p=.109)\end{array}$ \\
\hline
\end{tabular}

Note: all models include a control for the rights practice in 2000 .

empowered vis-à-vis their governments - there is even a negative, albeit weak, correlation. In two cases involving physical integrity and torture (which are highly correlated with a Pearson's correlation coefficient of .81) the presence of a website is associated weakly with improved outcomes. In the case of torture, legal transparency might be weakly correlated with a slight reduction in torture. NHRIs whose websites post human rights reports (and responses) and those that answer e-mail requests for information on what to do about a potential rights violation are associated with improved workers' rights. As one might expect, the World Governance Indicator of 'voice and accountability', which measures perceptions of the extent to which a country protects certain civil and political rights such as freedom of expression and a free media, is somewhat higher for NHRIs that bother to answer e-mail inquiries. We reiterate our caution about these findings. But they do seem to point to 
the possibility that NHRIs alone are not enough. While it may be marginally useful to encourage transparency by explaining the law, by reporting on government practices, and by responding to requests for information about options in the case of possible violation, this type of human rights transparency may not be sufficient in and of itself to bring about short-term improvements in human rights practices. Future research should monitor the extent of transparency offered by NHRIs, to track whether in fact these weak results can be fortified over time.

\section{Conclusion}

Notably, most countries have now established some type of a national human rights institution, and a large proportion of these NHRIs employ websites to disseminate human rights information. This in itself is striking, and in this respect NHRIs have followed the general trend toward e-government adopted by many regulatory and other governmental agencies. And as with other forms of e-government, wealthier and more democratic countries with a strong rule of law or high quality civil service agencies are more likely to set up an NHRI website. Intuitively we might also expect countries with more internet users to expend more resources and effort in setting up government websites and providing more information on these sites, but we find this is only partly the case for NHRIs. Internet penetration of a country is not associated with the existence of an NHRI website, although countries with a higher percentage of internet users do tend to have NHRI websites that are more transparent, particularly with respect to domestic human rights law.

While there seems to be a clear pattern in the setting up of NHRI websites, the quality and accessibility of these websites vary tremendously. NHRIs display significant differences in both the level and type of human rights transparency found on their websites. In contrast to the 'isomorphism' in NHRI structures identified by some studies, there appears to be no analogous 'isomorphism' with respect to NHRI websites. Governments may decide to establish an NHRI for any number of reasons, and the powers and independence given to an NHRI (and thus the extent to which it is permitted to be transparent) are often related to the original motive or purpose for supporting its initial creation. We believe it likely that only States already committed to improving their human rights practices will support greater NHRI transparency. And in fact, countries with better human rights practices that have ratified more international human rights conventions are slightly more likely to have 
NHRIs which provide greater legal transparency on their websites. Interestingly though, democratic governance per se does not seem to be related to the quality and accessibility of these websites. Additionally, we recognize that in some contexts NHRIs may be subject to significant government pressure to dissuade criticism of its practices, and thus a measure of NHRI independence from the government might well be an important factor in explaining the extent to which it is able to be transparent. One useful avenue for further research would be to examine this relationship between NHRI independence and transparency.

As mentioned earlier, the UN OHCHR and other international and regional organizations have been at the forefront of the recent push for NHRI creation worldwide, largely because of the belief that these institutions are key to ensuring domestic implementation and promotion of international human rights obligations. Yet, as demonstrated above, a relatively small proportion of these institutions actually reference or provide information about international human rights obligations and processes. While this might be a bit disappointing, it is notable that those NHRIs that do rate high on international human rights transparency are institutions that have been established more recently. One possible reason that newly-established NHRIs are more likely to highlight international human rights is the fact that they may have been created in response to recent pressure from the UN OHCHR and other international bodies, who might be expected to emphasize these international obligations.

While greater transparency by an NHRI of a government's human rights practices may be desirable in and of itself, the more interesting question is whether NHRI transparency affects government compliance with a State's human rights obligations. If, as advocates of transparency argue, transparency improves governance by providing disenfranchised citizens and groups with more information to push for political change, then we would expect increased human rights transparency to provide civil society with more information around which to organize and mobilize, providing leverage to increase pressure on governments. Greater transparency would thus encourage more organization and mobilization by civil society groups, who use this information to put pressure on the government to change its human rights practices. At this time, it is impossible to empirically assess this causal argument, but as we have shown NHRI transparency is only weakly correlated with human rights improvements over the past decade. We suspect this partly may be because the existence of an NHRI - even one that provides high quality 
and accessible information about human rights law, practices and remedies - is not enough to guarantee short-term improvements in actual rights practices. While this type of transparency may be marginally useful and inherently desirable, its utility in changing government practices may also depend on a number of other factors, such as time, the presence of a strong civil society, a free press, or other political and civil liberties. Future research should continue to monitor the extent of transparency offered by NHRIs, to track whether in fact such transparency helps bring about longer-term improvements in human rights. 
